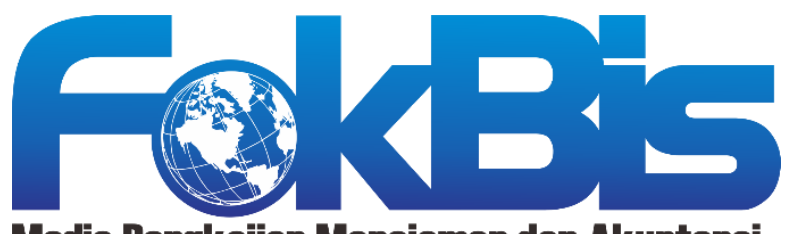

Media Pengkajian Manajemen dan Akuntansi

http://journal.stieputrabangsa.ac.id/index.php/fokbis/index

ISSN: 2623-2480/ P-ISSN: 1693-5209

\title{
Pengaruh Gamifikasi Terhadap Loyalitas Pelanggan Jaringan Hotel Internasional di Surabaya
}

\author{
Rean Mitasari ${ }^{1}$, Erris Kusumawidjaya ${ }^{2}$ \\ 1,2) Universitas Ciputra Surabaya \\ email: ${ }^{1)}$ rean.mitasari@ciputra.ac.id
}

\section{Article Information}

\section{History of Article:}

Received September $30^{\text {th }} 2020$

Accepted December $23^{\text {th }} 2020$

Published December $31^{\text {st }} 2020$

\section{DOI:}

10.32639/ fokusbisnis.v19i2.667

\begin{abstract}
ABSTRAK
Di era teknologi 4.0 sekarang ini, seluruh sektor industri dituntut untuk menggunakan internet \& perangkat teknologi terkini dalam menjalankan proses bisnisnya.Dalam industri pariwisata, khususnya akomodasi, sebuah sistem bernama gamifikasi menjadi salah satu tren yang diterapkan dalam bentuk aplikasi seluler yang dilakukan oleh berbagai jaringan hotel internasional. Dengan menyisipkan fitur pada game seperti tier (tingkatan/level), nilai (point), dan penghargaan (reward), para pelanggan diharapkan dapat lebih menggunakan produk-produk yang ditawarkan oleh pihak hotel. Oleh sebab itu, artikel ini mencoba untuk meneliti sejauh mana gamifikasi dapat mempengaruhi loyalitas pelanggan jaringan hotel internasional di Surabaya. Data penelitian dikumpulkan dari penyebaran kuesioner secara online kepada para pelanggan yang terdaftar sebagai anggota program loyalitas jaringan hotel internasional di Surabaya. Hasil penelitian inimenunjukkan bahwa loyalitas pelanggan jaringan hotel internasional di Surabaya sangat dipengaruhi oleh keuntungan yang diperoleh dari program loyalitas yang disajikan dalam bentuk aplikasi seluler.
\end{abstract}

Kata Kunci: Gamifikasi, Loyalitas Pelanggan, Program Loyalitas, Aplikasi Seluler, Bisnis Akomodasi

\begin{abstract}
In this 4.0 technology era, all industry sectors are required to make use of the internet and latest technology for running their business process. In tourism industry, especially accommodation, a system named gamification becomes one of the trends applied in the form of mobile application done by various international hotel chains. By inserting game features such as tier (level), point, and reward, customers are expected to be more loyal by using those features embedded in the application. Therefore, this paper aims to examine to what extent gamification is able to influence customer loyalty of international hotel chain in Surabaya. The data was collected by distributing online questionnaire to the customers registered as loyalty program's members of international hotel chain in Surabaya. The study reveals that customer loyalty of international hotel chain in Surabaya strongly influenced by the benefits obtained from the loyalty program provided in the form of mobile application.
\end{abstract}

Keywords: Gamification, Customer Loyalty, Loyalty Program; Mobile Application, Accommodation Business 


\section{PENDAHULUAN}

Promosi, pemasaran, pengembangan, dan pemesanan produk pariwisata saat ini hampir semua dilakukan dengan memanfaatkan teknologi atau bersifat digital. Berbagai aplikasi untuk memudahkan wisatawan melakukan kegiatan wisata bermunculan dan mudah didapatkan pada gawai (gadget). Menurut Pamfilie, Vasilcovschi, \& Bumbac (2016), dinyatakan bahwa aplikasi dengan tampilan menarik menimbulkan perasaan senang dan menjadi pilihan wisatawan untuk mengeksplorasi destinasi wisata baru. Pamfilie et al. (2016) juga menambahkan bahwa kemudahan dalam mengoperasikan aplikasi juga mendorong wisawatan untuk menemukan tempat-tempat baru untuk dikunjungi.

Salah satu moda pengoperasian aplikasi dalam dunia pariwisata yang sedang populer saat ini adalah gamifikasi. Gamifikasi membuat seolah-olah wisatawan sedang memainkan permainan digital (game) meskipun bukan dalam konteks game itu sendiri (Deterding, Dixon, Khaled, \& Nacke, 2011). Beberapa fitur dalam game seperti pencarian lokasi (locating place), pelacakan (tracing), tingkatan keanggotaan (level), nilai (point), dan bonus hadiah (reward) diadopsi dalam menggunakan jasa pariwisata dan mengeksplorasi destinasi yang sedang dikunjungi oleh wisatawan (Mehrbod, Mehrbod, Grilo, Vasconcelos, \& Silva, 2018; Werbach \& Hunter, 2012). Dengan adanya reward dan point yang akan diperoleh pengguna aplikasi, mereka dapat meningkatkan level dengan menggunakan fitur-fitur yang tersedia. Melihat trend tersebut, berbagai pemilik usaha jasa pariwisata mulai menerapkan sistem serupa untuk mendapatkan pelanggan.

Penerapan moda gamifikasi yang paling mudah ditemui adalah pada usaha akomodasi. Berbagai aplikasi seperti Traveloka, Pegipegi, Tiket.com, Mister Aladin, Agoda, Booking.com, dan masih banyak lagi dapat dengan mudah diunduh dan digunakan oleh para wisatawan untuk memesan akomodasi wisata. Dengan memasukkan nama destinasi, wisatawan dengan mudah menemukan berbagai nama penyedia usaha akomodasi di daerah tersebut dan melakukan pemesanan kamar. Setelah melakukan pemesanan, terdapat pemberian point bagi wisatawan dan tingkat keanggotaannya pun meningkat. Saat point maupun tingkatan (level) keanggotaan telah mencapai nilai tertentu,akan ada reward yang diberikan sebagai bentuk apresiasi telah menggunakan aplikasi tersebut.

Tersedianya aplikasi pemesanan akomodasi membuat persaingan usaha jasa semakin kompetitif (BOZ, 2016)dan meningkatkan pengalaman pelanggan dalam menggunakan suatu jasa layanan (Huotari \& Hamari, 2012). Hotel berbintang pun menerapkan sistem serupa dengan memberikan program loyalitas (loyalty program) kepada para tamu yang menggunakan layanan hotel tersebut. Beberapa program loyalitas dari hotel jaringan terkemuka seperti Accor, Shangri-La, Marriot, IHG, InterContinental Hotel, Hilton, dan hotel bintang lainnya menggunakan sistem gamifikasi penukaran poin (point redeem) dan apresiasi (rewarding). Dengan menggunakan sistem tersebut, berbagai fasilitas dan keuntungan dapat diperoleh oleh tamu/wisatawan yang menjadi anggota dari program loyalitas. Karena hotel berbintang adalah hotel dengan sistem jaringan, tentunya keuntungan tadi juga tersebar di berbagai wilayah jaringan hotel tersebut.

Adanya program loyalitas dari jaringan hotel berpengaruh terhadap loyalitas pelanggan dari hotel-hotel tersebut. Seseorang dikatakan memiliki loyalitas bila sudah melakukan pembelian rutin, membeli produk diluar dari produk yang biasanya ditawarkan, merekomendasikan kepada yang lain, dan tidak terpengaruh oleh kompetitor lain (Griffin, 1996, 2010). Johnson (2015) dan Nyadzayo \& Khajehzadeh (2016), loyalitas dipengaruhi oleh kualitas pelayanan, kualitas produk, strategi harga, dan atribut tempat. Sehingga dapat dikatakan bahwa seseorang setia menggunakan suatu produk maupun jasa karena ada ketertarikan akan layanan berikut dengan keuntungan yang diperoleh. Hal itu juga membuat pelanggan tidak berpindah ke penyedia jasa lain karena belum tentu akan mendapatkan pelayanan dan keuntungan yang sama dengan yang didapatkan saat ini(Nugroho, Oktavio, \& Kartika, 2019).

Dari paparan yang sudah diuraikan di atas, gamifikasi menjadi atribut tersendiri yang diberikan oleh penyedia jasa bagi pelanggannya. Selain itu, gamifikasi juga sedang menjadi tren dalam dunia pariwisata, khususnya dalam jasa akomodasi. Didasarkan pada dua hal tersebut, penelitian ini bertujuan untuk 
mengkaji pengaruh gamifikasi yang ada pada jaringan hotel internasional di Surabaya terhadap loyalitas pelanggan. Gamifikasi yang dimaksud adalah penerapan konten game dalam aplikasi program loyalitas yang dimiliki oleh jaringan hotel internasional di Kota Surabaya.

\section{KAJIAN LITERATUR DAN PENGEMBANGAN HIPOTESIS}

\section{Gamifikasi}

Gamifikasi adalah penerapan teknik desain dan elemen game dalam konteks non-game (Deterding et al., 2011; Huotari \& Hamari, 2012; Zuo, Xiong, \& lida, 2017). Gamifikasi menurut Alsawaier (2018) dimaksudkan untuk meningkatkan motivasi, kesenangan, dan keterlibatan dengan produk dan pengguna layanan tertentu. Zuo et al. (2017) mengilustrasikan ketiga bagian utama dari konsep gamifikasi sebagai berikut:

1. Game Elements: layanan yang dibangun oleh perancang game dengan menggunakan bagian dan potongan dari game.

2. Game Design: penerapan gamifikasi memanfaatkan keinginan alami seseorang untuk belajar, berprestasi, berkompetisi, dan bersosialisasi. Salah satu cara yang dapat digunakan untuk mendorong persaingan adalah dengan memberikan hadiah ketika pemain dapat menyelesaikan tugas, yang dapat dilihat oleh pemain lain atau menggunakan papan peringkat.

3. Non-Game Context: konteks non-game dipahami sebagai segala sesuatu selain permainan itu sendiri, di mana tujuannya berada di luar permainan. Sebagai contoh, para pemain memainkan permainan karena alasan yang terkait dengan kebutuhan atau bisnis mereka. Dengan demikian, gamification berarti beberapa kegiatan sosial yang melibatkan beberapa kombinasi elemen game dan desain game dengan tujuan selain bermain game.

\section{Gamifikasi pada Program Loyalitas}

Program loyalitas adalah taktik pemasaran yang bertujuan membangun dan mempertahankan loyalitas merek melalui skema hadiah yang direncanakan berdasarkan riwayat pembelian pelanggan (Kim \& Ahn, 2017b, 2017a; Sharp \& Sharp, 1997).

Program loyalitas hotel merupakan strategi penting untuk jaringan hotel. Program ini umumnya terdiri dari dua mekanisme (Zuo et al., 2017):

\section{Sistem Tingkatan}

Sistem ini merupakan sistem yang umum ada dalam program loyalitas hotel dan menjadi dasar dari struktur program tersebut. Tingkat pertama saat tamu masuk sebagai member dengan mendaftarkan nama, alamat, dan informasi pribadi lainnya. Mereka umumnya akan mendapatkan keuntungan standar dan cenderung melakukan beberapa pembelian dengan tujuan mendapatkan poin. Tingkat tengah dari membership program umumnya adalah segmen pasar yang tinggal di hotel secara berkala. Sementara tingkat teratas dari membership program hotel adalah segmen pasar yang sering menginap di hotel dengan lebih dari 60 malam per tahun.

\section{Sistem Poin}

Meskipun beberapa keuntungan terkait dengan tingkatan yang dimiliki anggota, kesenangan terutama yang dirasakan oleh mereka adalah ketika mereka dapat menukarkan poin yang dikumpulkan dengan gratis menginap. Poin-poin yang diberikan dalam program loyalitas hotel dimaksudkan untuk member 
keseimbangan bagi pelanggan yang sering datang ke hotel. Poin umumnya dihitung dari masa tinggal yang memenuhi persyaratan tertentu. Poin ini kemudian dikumpulkan untuk kemudian ditukarkan dengan satu malam gratis untuk menginap. Sistem tingkatan biasanya akan memberikan keuntungan berupa rasio poin yang lebih besar.

Zuo et al. (2017) menjelaskan bahwa gamifikasi dalam konteks hotel loyalty program dapat dipersempit lingkup dan definisinya menjadi peningkatan layanan dan poin ketika status keanggotaan meningkat dengan menggunakan elemen games yang terorganisir dengan baik untuk memberikan pengalaman permainan dalam usaha mempertahankan loyalitas pelanggan terhadap merek hotel.

Contoh penerapan gamifikasi yang dapat ditemukan pada program loyalitas hotel antara lain penerapan Game Elements pada halaman beranda hotel rewards program yangdapat melihat antar muka grafis yang umumnya ditemukan dalam permainan, seperti level, poin, progression, promotion dan badges. Contoh lainnya adalah penerapan Game Design pada program loyalitas pelanggan hotel melalui sistem poin dan tingkatan dimana elemen permainan diatur secara sistematis dan perasaan sedang bermaingame ditawarkan agar dapat mendorong pelanggan untuk menikmati aktivitas.

\section{Loyalitas Pelanggan}

Dalam konteks di mana persaingan hotel semakin kompetitif dan perkembangan teknologi yang semakin pesat, loyalitas pelanggan menjadi salah satu tantangan besar untuk meningkatkan profitabilitas hotel (Kandampully, Zhang, \& Jaakkola, 2018).Loyalitas pelanggan menurut Bahri-Ammari, Van Niekerk, Ben Khelil, \& Chtioui (2016) dan Lee (2019) mengacu kepada derajat keterikatan yang dimiliki pelanggan kepada brand tertentu. Loyalitas terhadap destinasi dapat didefinisikan sebagai tingkat keterikatan dan sikap positif individu terhadap destinasi yang dapat dilihat melalui minat berkunjung kembali maupun minat untuk mempromosikan destinasi tersebut (Alegre \& Juaneda, 2006; Almeida-Santana \& MorenoGil, 2018). Griffin (2010) dan Oke, Kamolshotiros, Popoola, Ajagbe, \& Olujobi (2016) mendefinisikan loyalitas pelanggan sebagai suatu perilaku pembelian non acak yang ditunjukkan dari waktu ke waktu melalui serangkaian pengambilan keputusan. Loyalitas merujuk pada sebuah bentuk kesetiaan sebagai konsekuensi dari adanya hubungan jangka panjang yang positif antara penyedia layanan dan pelanggan (Gupta, Gupta, \& Shainesh, 2018). Dengan demikian, pelanggan yang setia adalah pelanggan yang sebagian besar membeli kembali, jika memungkinkan, dari penyedia yang sama dan mempertahankan sikap positif terhadap penyedia layanan.

Dimensi perilaku loyalitas mengacu pada aspek-aspek perilaku konsumen seperti pembelian berulang yang diarahkan pada merek atau layanan tertentu dari waktu ke waktu (Oke et al., 2016). Meskipun pembelian berulang merupakan masalah penting, interpretasi loyalitas berdasarkan perilaku pembelian saja tidaklah cukup, karena perilaku pembelian tidak selalu menunjukkan motivasi pelanggan untuk melakukan pembelian berulang (M. Lee \& Cunningham, 2001). Pelanggan dapat membeli kembali dari penyedia yang sama untuk alasan lain selain dari perasaan pribadinya yang positif terhadap suatu perusahaan. Misalnya, dalam industri perhotelan, pelanggan mungkin akan tetap menggunakan jasa layanan hotel tertentu karenaalasan ketidakpedulian terhadap kualitas hotel, properti hotel tersebut yang paling dapat diterima oleh pelanggan; atau hotel dianggap yang terbaik dari sekumpulan alternatif yang buruk yang tersedia di sebuah destinasi.

\section{METODE PENELITIAN}

Penelitian ini dilakukan selama bulan Februari-April 2020 dengan tujuan untuk mencari hubungan kausal antar variabel yang diteliti sehingga penelitian ini termasuk dalam penelitian kuantitatif eksplanatif. Variabel bebas pada penelitian ini adalah gamifikasi $(X)$, sedangkan variabel terikat pada penelitian ini adalah loyalitas pelanggan $(\mathrm{Y})$. Pengukuran variabel gamifikasi menggunakan 3 indikator yang diadopsi 
dari penelitian Zuo et al. (2017) yang dituangkan dalam butir-butir pernyataan di kuesioner seperti meningkatkan tier keanggotaan di program loyalitas hotel, mengumpulkan point di program loyalitas hotel, dan mendapatkan reward dari program loyalitas hotel. Sedangkan variabel loyalitas pelanggan diukur dengan 4 indikator milik Griffin (1996) seperti menginap kembali di grup hotel yang sesuai dengan program loyalitas yang dimiliki, merekomendasikan kepada orang lain untuk menginap di grup hotel sesuai dengan program loyalitas yang dimiliki, menyewa jasa transportasi yang ditawarkan di grup hotel yang sesuai dengan program loyalitas yang dimiliki, dan menyampaikan pada pihak hotel yang sesuai dengan program loyalitas yang dimilikibila ada keluhan selama menginap.

Target populasi untuk pengumpulan data penelitian adalah tamu-tamu yang pernah menginap di hotel yang termasuk dalam grup jaringan hotel internasional dan terdaftar sebagai anggota program loyalitas yang jumlahnya tidak diketahui secara pasti. Berdasarkan data dari www.tripadvisor.com yang merupakan salah satu situs ulasan perjalanan, terdapat 19 hotel yang termasuk di 9 grup jaringan hotel internasional yang ada di Surabaya dan memiliki program loyalitas. Atas dasar itulah, maka peneliti menyebarkan kuesioner dalam format google form ke sejumlah alamat email pelanggan yang telah menginap di sejumlah hotel yang masuk di jaringan hotel internasional di Surabayamelalui situs ulasan TripAdvisor. Dari hasil penyebaran kuesioner tersebut pada akhirnya peneliti mendapatkan 101 responden sebagai sampel penelitian ini.

\section{Metode Analisis Data}

Data yang diperoleh dalam penelitian ini selanjutnya diolah dengan program SPSS 22 dan teknik analisis regresi linear sederhana sesuai dengan model penelitian pada Gambar 1.

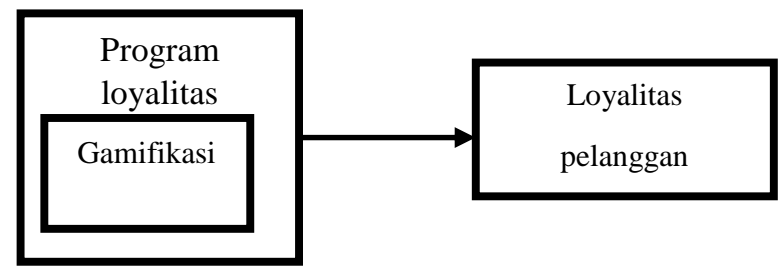

Gambar 1. Model penelitian

\section{HASIL DAN PEMBAHASAN}

\section{Deskripsi Responden}

Dari survei yang dilakukan, terdapat informasi demografi yang beragam dari para responden yang menggunakan jasa jaringan hotel internasional seperti variasi dalam usia, pekerjaan, kewarganegaraan, nama program loyalitas yang diikuti, dan lama menjadi anggota program loyalitas. Sebesar $30,8 \%$ responden adalah mereka yang berada di usia produktif, yaitu usia 30-34 tahun, sisanya berada di usia $25-29$ tahun (18,8\%), 35-39 tahun (22,2\%), diatas 40 tahun $(25,6 \%)$, dan yang terendah adalah usia 2-24 tahun (2,6\%). Meskipun usia 20-24 termasuk dalam usia produktif, namun mereka yang berusia 3034 tahun memiliki pekerjaan yang membuat mereka memiliki daya beli akan jasa yang ditawarkan oleh hotel jaringan internasional. Daya beli yang tinggi mendorong seseorang untuk membelijasa yang ditawarkan oleh penyedia jasa (Gelb \& Diofasi, 2015), dalam hal ini hotel jaringan internasional. Hal ini berarti bahwa mereka yang berusia 30-34 tahun cenderung memiliki daya beli tinggi karena didukung oleh pekerjaan yang mereka miliki. Sedangkan jenis pekerjaan yang memiliki persentase tertinggi sebagai pengguna program loyalitas berdasarkan hasil survei adalah industri kreatif, yaitu sebesar $19,1 \%$, diikuti oleh pegawai swasta dan lainnya, masing-masing memiliki persentase $17 \%$, dan sisanya adalah tenaga medis (14,9\%), wiraswasta (12,8\%), pegawai negeri sipil (10,6\%), akademisi $(4,7 \%)$, dan mahasiswa $(4,7 \%)$. 
Hasil survei juga menunjukkan bahwa respondenberjenis kelamin laki-laki lebih banyak memiliki atau mengikuti program loyalitas hotel jaringan internasional dibandingkan dengan pelanggan yang berjenis perempuan. Hal itu ditunjukkan oleh persentase jumlah responden laki-laki yaitu 52,1\%, sedangkan responden berjenis kelamin perempuan sebesar $47,9 \%$. Selain itu, hasil survei juga menunjukkan bahwa para tamu tidak hanya berasal dari Indonesia saja tetapi juga dari luar negeri seperti dari Amerika, Inggris, Belanda, Denmark, Cina, Taiwan, Singapura, dan Malaysia. Sehingga cukup banyak tamu asing yang juga merupakan anggota program loyalitas yang menginap di hotel-hotel jaringan internasional yang terdapat di Surabaya.

Di dalam ulasan yang diberikan respondenpada laman ulasan hotel diTripadvisor,mereka menyebutkan posisi tier yang diraih dan posisi tersebut berada dalam posisi yang tinggi yaitu Gold dan Platinum. Dari informasi tersebut, tingginya tingkatan tier yang diperoleh oleh responden membuktikan bahwa mereka cukup sering memanfaatkan kelebihan yang ditawarkan dalam program loyalitas.Tingginya tier yang diperoleh oleh para responden juga dapat terkait dengan lamanya mereka terdaftar sebagai anggota program loyalitas itu sendiri. Dari hasil survei, sebesar $47,6 \%$ responden terdaftar menjadi anggota program loyalitas selama 1-3 tahun, kemudian sebesar 19\% responden terdaftar sebagai anggota program loyalitas selama 3-5 tahun dan lebih dari 6 bulan. Sedangkan bagi mereka yang terdaftar selama lebih dari 5 tahun dan kurang dari 6 bulan masing-masing berjumlah 7,1\%. Jika dilihat dari jumlah para responden yang terdaftar dalam rentang tahunan, besar kemungkinan bagi mereka untuk mencapai tier yang lebih tinggi karena telah menggunakan keuntungan yang ada dalam program loyalitas tersebut di waktu yang cukup lama.

\section{Validitas dan Reliabilitas}

Dalam pengolahan data, peneliti melakukan uji validitas dan reabilitas terlebih dahulu sebelum melakukan uji hipotesis dan analisa hasil. Untuk menguji validitas, peneliti menggunakan uji pearson correlation dan uji reabilitas menggunakan cronbach's alphaseperti yang tersaji dalam Tabel 1 dan Tabel 2.

Tabel 1. Uji Validitas

\begin{tabular}{llllll}
\hline Variabel & Gamifikasi & Keterangan & Variabel & $\begin{array}{l}\text { Loyalitas } \\
\text { Pelanggan }\end{array}$ & Keterangan \\
\hline x1 & $.860^{* *}$ & Valid & y1 & $.860^{* *}$ & Valid \\
x2 & $.887^{* *}$ & Valid & y2 & $.887^{* *}$ & Valid \\
x3 & $.923^{* *}$ & Valid & y3 & $.923^{* *}$ & Valid \\
& & & y4 & $.790^{* *}$ & Valid \\
\hline
\end{tabular}

${ }^{* *}$ Angka korelasi signifikan pada level 0.01 (2-tailed)

Dari Tabel 1, dapat diketahui bahwa indikator-indikator yang digunakan untuk mengukur semua variabel Gamifikasi dan Loyalitas Pelanggan adalah valid. Pada Tabel 2, diketahui bahwa uji reliabilitas yang dilakukan oleh peneliti menunjukkan nilai cronbach's alpha untuk kedua variabel adalah di atas 0.6. Sehingga dapat dikatakan bahwa instrumen yang dipakai peneliti adalah reliabel.

Tabel 2. Uji Reliabilitas

\begin{tabular}{llll}
\hline Variabel & Alpha & Cut-off & Keterangan \\
\hline Gamifikasi & 0.862 & 0.6 & Reliabel \\
Loyalitas Pelanggan & 0.886 & 0.6 & Reliabel \\
\hline
\end{tabular}




\section{Uji Hipotesis}

Peneliti melakukan analisis statistik deskriptif pada data yang diperoleh sebelum uji hipotesis dilakukan. Hasil dari analisis deskriptif tersebut seperti yang nampak pada Tabel 3.

Tabel 3. Analisa Statistik Deskriptif

\begin{tabular}{|c|c|c|c|}
\hline Variabel & Mean & Kategori & Std. Deviasi \\
\hline Peningkatan Tier & 2.95 & Baik & 0.91 \\
\hline Peningkatan Point & 3.24 & Baik & 0.98 \\
\hline Mendapatkan Reward & 2.86 & Baik & 1.23 \\
\hline Rata-rata Gamifikasi & 3.02 & Baik & 1.06 \\
\hline Pembelian kembali & 3.27 & Sangat Baik & 0.89 \\
\hline $\begin{array}{l}\text { Merekomen-dasikan } \\
\text { kepada orang lain }\end{array}$ & 2.96 & Baik & 1.17 \\
\hline Pembelian lintas lini & 3.46 & Sangat Baik & 0.83 \\
\hline $\begin{array}{l}\text { Berani menyampai-kan } \\
\text { keluhan }\end{array}$ & 2.81 & Baik & 1.03 \\
\hline $\begin{array}{ll}\text { Rata-rata } & \text { Loyalitas } \\
\text { Pelanggan } & \end{array}$ & 3.12 & Baik & 1.01 \\
\hline
\end{tabular}

Dari hasil analisa pada Tabel 3, nilai setiap indikator dari variabel gamifikasi dan loyalitas pelanggan berada pada kategori baik. Standar deviasi yang ditunjukkan berada disekitar angka 1 dimana hal tersebut berarti semakin besar nilai standar deviasi suatu data maka semakin besar jarak setiap titik data dengan nilai ratarata. Jawaban dari para responden memang cukup beragam, namun tidak terlalu melebar yang berarti masih cukup homogen.

Selanjutnya, peneliti melakukan uji hipotesis dengan maksud apakah hipotesis dalam penelitian ini diterima atau ditolak. Hasil dari uji hipotesis ditunjukkan pada Tabel 4.

Tabel 4. Uji Hipotesis

\begin{tabular}{llll}
\hline Variabel & Koefisien $\beta$ & $\mathrm{T}$ & Signifikansi \\
\hline (constant) & 2.902 & 5.015 & 0.000 \\
Gamifikasi & 1.060 & 17.340 & 0.000 \\
\hline
\end{tabular}

Dari Tabel 4, ditunjukkan bahwa koefisien $\beta$ pada gamifikasi adalah 1.060 dengan nilai signifikansi 0,000. Oleh karena itu dapat disimpulkan bahwa gamifikasi memiliki pengaruh positif dan signifikan terhadap loyalitas pelanggan. Sehingga hipotesis dalam penelitian ini dapat diterima. Selain dari koefisien nilai $\beta$, peneliti juga menggunakan ujiR-squared yang nampak dalam Tabel 5.

Tabel 5. Uji R-Squared

\begin{tabular}{lll}
\hline Pengaruh & R Square & Adjusted R Square \\
\hline Gamifikasi $\rightarrow$ Loyalitas Pelanggan & 0.752 & 0.750 \\
\hline
\end{tabular}

Dari tabel 5 diketahui bahwa nilai $R$-Squared adalah 0.752, dan nilai Adjusted $R$-Squared adalah 0,750. Artinya, variabel gamifikasi dapat menjelaskan variabel loyalitas pelanggan sebesar $75,2 \%$ atau $75 \%$. Sedangkan sisanya dijelaskan oleh variabel-variabel lain yang tidak disertakan dalam dalam penelitian ini.

Hasil penelitian ini mendukung temuan sebelumnya dengan didukungnya hipotesis yang ada. Penelitian yang dilakukan oleh Zatwarnicka-Madura (2015) dan Fiorletta (2012) menyatakan bahwa gamifikasi berpengaruh terhadap loyalitas pelanggan. Meskipun para responden dari penelitian tersebut bukan pelanggan hotel jaringan internasional dan tidak semua indikator yang digunakan oleh peneliti terdahulu 
tersebut juga dipakai dalam penelitian ini, namun hasil dari penelitian terdahulu menyatakan bahwa gamifikasi memberikan pengaruh yang positif dan signifikan terhadap loyalitas pelanggan. Dengan kata lain, semakin modern suatu sistem yang digunakan oleh sebuah penyedia jasa, semakin tinggi loyalitas pelanggan karena adanya sarana yang memberikan keuntungan setelah mengkonsumsi jasa tersebut. Keuntungan yang didapat oleh para pelanggan tersebut antara lain, meningkatnya tier dan point yang berujung adanya reward yang diterima oleh para pelanggan.

Adanya program loyalitas dalam bentuk digital membuka luas akses bagi para pelanggan terhadap berbagai jasayang ditawarkan oleh penyedia jasa (Dorotic, 2019). Salah satu indikator loyalitas pelanggan dengan nilai mean tertinggi adalah pembelian lintas lini, dimana dalam aplikasi seluler program loyalitas berbagai jasa hotel internasional selain akomodasi juga ditawarkan. Pelanggan akan lebih mudah menjangkau penawaran jasa lain tersebut dan melakukan pembelian di aplikasi yang sama. Semakin mudah seseorang mengakses jasa yang ditawarkan, semakin besar loyalitas yang didapatkan oleh penyedia jasa dari pelanggannya. Sehingga penerapan gamifikasi dalam program loyalitas berpengaruh positif tehadap kesetiaan pelanggan jaringan hotel internasional dalam memanfaatkan jasa yang ditawarkan.

Selain itu, indikator tertinggi dari loyalitas pelanggan adalah pembelian kembali. Hal ini dapat berkaitan dengan keuntungan yang didapatkan oleh pelanggan selain dari kemudahan mendaptkan jasa melalui program loyalitas. Hal tersebut juga didukung dari hasil penelitian terdahulu yang dilakukan oleh McMullan \& Gilmore (2008), yang menyatakan bahwa pelanggan akan melakukan pembelian jasa kembali karena merasa mendapatkan keuntungan lebih dari konsumsi jasa yang dilakukan. Keinginan untuk kembali mendapatkan keuntungan dari pembelian jasa di hotel jaringan internasional melalui program loyalitas membuat para pelanggan melakukan pembelian jasa berulang dari penyedia jasa yang sama. Semakin sering pelanggan melakukan pembelian berulang di tempat yang sama, semakin tinggi rasa percaya yang diperoleh penyedia jasa tersebut dari para pelanggannya.

Meskipun gamifikasi berpengaruh positif, namun keinginan merekomendasikan kepada orang lain dan menyampaikan keluhan saat pelanggan menginap di hotel jaringan internasional memiliki nilai mean sedikit lebih rendah dibandingkan dua indikator lain. Kontak langsung antara pelanggan dengan pihak penyedia jasa tetap diperlukan meski sudah difasilitasi oleh sebuah sistem modern yang baik (Voorhees et al., 2017). Hal tersebut dimaksudkan agar kepercayaan para pelanggan semakin tinggi lagi dari sebelumnya karena pihak penyedia jasa menanggapi secara langsung keluhan dari para pelanggan (Wolf, Weiger, \& Hammerschmidt, 2018). Selain itu, rekomendasi kepada orang lain dapat menarik minat dari para calon pelanggan dalam menggunakan jasa yang ditawarkan oleh pihak hotel jaringan internasional melalui program loyalitas berbasis gamifikasi (Voorhees et al., 2017).

\section{SIMPULAN}

Penerapan konten games (gamifikasi) dimaksudkan untuk membuat para pelanggan merasa senang dan lebih dekat dengan penyedia produk atau jasa. Adanya moda gamifikasi dalam program loyalitas pada hotel-hotel jaringan internasional di Surabaya memberikan pengaruh yang positif pada loyalitas pelanggannya. Program loyalitas dengan penerapan sistem yang modern membuat para pelanggan lebih percaya akan layanan hotel jaringan internasional di Surabaya.

\section{REFERENSI}

Alegre, J., \& Juaneda, C. (2006). Destination loyalty. Consumers' economic behavior. Annals of Tourism Research, 33(3), 684-706. https://doi.org/10.1016/j.annals.2006.03.014 
Almeida-Santana, A., \& Moreno-Gil, S. (2018). Understanding tourism loyalty: Horizontal vs destination loyalty. Tourism Management, 65, 245-255. https://doi.org/10.1016/j.tourman.2017.10.011

Alsawaier, R. S. (2018). The effect of gamification on motivation and engagement. International Journal of Information and Learning Technology, 35(1), 56-79. https://doi.org/10.1108/IJILT-02-20170009

Bahri-Ammari, N., Van Niekerk, M., Ben Khelil, H., \& Chtioui, J. (2016). The effects of brand attachment on behavioral loyalty in the luxury restaurant sector. International Journal of Contemporary Hospitality Management, 28(3), 559-585. https://doi.org/10.1108/IJCHM-10-2014-0508

Boz, M. (2016). Online booking as a marketing strategy: A survey on hotels in Antalya. IOSR Journal of Business and Management, 18(09), 78-85. https://doi.org/10.9790/487x-1809047885

Deterding, S., Dixon, D., Khaled, R., \& Nacke, L. (2011). From game design elements to gamefulness: Defining "gamification." In Proceedings of the 15th International Academic MindTrek Conference: Envisioning Future Media Environments, MindTrek 2011 (pp. 9-15). https://doi.org/10.1145/2181037.2181040

Dorotic, M. (2019). Keeping loyalty programs fit for the digital age. NIM Marketing Intelligence Review, 11(1), 24-29. https://doi.org/10.2478/nimmir-2019-0004

Fiorletta, A. (2012). Leading retailers use gamification to boost customer engagement and loyalty. Retail $1-15$. Retrieved from https://pdfs.semanticscholar.org/b860/b57fd9b4283f58b201af574d2cfd80f96b6a.pdf

Gelb, A., \& Diofasi, A. (2015). What determines purchasing power parity exchange rates? SSRN Electronic Journal. https://doi.org/10.2139/ssrn.2671574

Griffin, J. (1996). The internet's expanding role in building customer loyalty. Direct Marketing, 59(7), 5053. Retrieved from http://www.highbeam.com/doc/1G1-19184833.html

Griffin, J. (2010). Customer loyalty: Menumbuhkan dan mempertahankan kesetiaan pelanggan. MIT Press Books.

Gupta, S., Gupta, T., \& Shainesh, G. (2018). Navigating from programme loyalty to company loyalty. IIMB Management Review, 30(3), 196-206. https://doi.org/10.1016/j.iimb.2018.01.009

Huotari, K., \& Hamari, J. (2012). Defining gamification - A service marketing perspective. In Proceedings of the 16th International Academic MindTrek Conference 2012: "Envisioning Future Media Environments", MindTrek 2012 (pp. 17-22). https://doi.org/10.1145/2393132.2393137

Johnson, M. D. (2015). Customer satisfaction. In International Encyclopedia of the Social \& Behavioral Sciences: Second Edition (pp. 630-632). https://doi.org/10.1016/B978-0-08-097086-8.73025-X

Kandampully, J., Zhang, T., \& Jaakkola, E. (2018). Customer experience management in hospitality: A literature synthesis, new understanding and research agenda. International Journal of Contemporary Hospitality Management, 30(1), 21-56. https://doi.org/10.1108/IJCHM-10-20150549

Kim, K., \& Ahn, S. J. G. (2017a). Rewards that undermine customer loyalty? A motivational approach to loyalty programs. Psychology and Marketing, 34(9), 842-852. https://doi.org/10.1002/mar.21026

Kim, K., \& Ahn, S. J. G. (2017b). The role of gamification in enhancing intrinsic motivation to use a loyalty program. Journal of Interactive Marketing. https://doi.org/10.1016/j.intmar.2017.07.001 
Lee, B. C. (2019). The effect of gamification on psychological and behavioral outcomes: Implications for cruise tourism destinations. Sustainability (Switzerland), 11(11). https://doi.org/10.3390/su11113002

Lee, M., \& Cunningham, L. F. (2001). A cost/benefit approach to understanding service loyalty. Journal of Services Marketing, 15(2), 113-130. https://doi.org/10.1108/08876040110387917

McMullan, R., \& Gilmore, A. (2008). Customer loyalty: An empirical study. European Journal of Marketing, 42(9-10), 1084-1094. https://doi.org/10.1108/03090560810891154

Mehrbod, A., Mehrbod, N., Grilo, A., Vasconcelos, C., \& Silva, J. L. (2018). Gamification in supported geocaching tours. In 2017 International Conference on Engineering, Technology and Innovation: Engineering, Technology and Innovation Management Beyond 2020: New Challenges, New Approaches, ICE/ITMC 2017 - Proceedings (Vol. 2018-January, pp. 1419-1423). https://doi.org/10.1109/ICE.2017.8280049

Nugroho, A., Oktavio, A., \& Kartika, E. W. (2019). Salesperson deviant behavior in Indonesian restaurant service attendants. International Review of Management and Marketing, 9(4), 1-6. https://doi.org/10.32479/irmm.8138

Nyadzayo, M. W., \& Khajehzadeh, S. (2016). The antecedents of customer loyalty: A moderated mediation model of customer relationship management quality and brand image. Journal of Retailing and Consumer Services, 30, 262-270. https://doi.org/10.1016/j.jretconser.2016.02.002

Oke, A. O., Kamolshotiros, P., Popoola, O. Y., Ajagbe, M. A., \& Olujobi, O. J. (2016). Consumer behavior towards decision making and loyalty to particular brands. International Review of Management and Marketing, 6(4), 43-52.

Pamfilie, R., Vasilcovschi, A., \& Bumbac, R. (2016). A new possible way of promoting tourist packages: Gamification. Cactus Tourism Journal, 13(1), 5-10.

Sharp, B., \& Sharp, A. (1997). Loyalty programs and their impact on repeat-purchase loyalty patterns. International Journal of Research in Marketing, 14(5), 473-486. https://doi.org/10.1016/s01678116(97)00022-0

Voorhees, C. M., Fombelle, P. W., Gregoire, Y., Bone, S., Gustafsson, A., Sousa, R., \& Walkowiak, T. (2017). Service encounters, experiences and the customer journey: Defining the field and a call to expand our lens. Journal of Business Research, 79, 269-280. https://doi.org/10.1016/j.jbusres.2017.04.014

Werbach, K., \& Hunter, D. (2012). For the win: How game thinking can revolutionize your business. Philadelphia: Wharton Digital Press.

Wolf, T., Weiger, W. H., \& Hammerschmidt, M. (2018). Gamified digital services: How gameful experiences drive continued service usage. In Proceedings of the 51st Hawaii International Conference on System Sciences. https://doi.org/10.24251/hicss.2018.147

Zatwarnicka-Madura, B. (2015). Gamification as a tool for influencing customers' behaviour. International Journal of Social, Behavioral, Educational, Economic, Business and Industrial Engineering, 9(5), 1424-1427. Retrieved from http://www.waset.org/publications/10001274

Zuo, L., Xiong, S., \& lida, H. (2017). An analysis of hotel loyalty program with a focus on the tiers and points system. In 2017 4th International Conference on Systems and Informatics, ICSAI 2017 (Vol. 2018Janua, pp. 507-512). https://doi.org/10.1109/ICSAI.2017.8248345 